\title{
Biology and significance of signalling pathways activated by IGF-II
}

DOI:

10.3109/08977194.2011.640325

\section{Document Version}

Accepted author manuscript

Link to publication record in Manchester Research Explorer

\section{Citation for published version (APA):}

Harris, L. K., \& Westwood, M. (2012). Biology and significance of signalling pathways activated by IGF-II. Growth Factors, 30(1), 1-12. https://doi.org/10.3109/08977194.2011.640325

\section{Published in:}

Growth Factors

\section{Citing this paper}

Please note that where the full-text provided on Manchester Research Explorer is the Author Accepted Manuscript or Proof version this may differ from the final Published version. If citing, it is advised that you check and use the publisher's definitive version.

\section{General rights}

Copyright and moral rights for the publications made accessible in the Research Explorer are retained by the authors and/or other copyright owners and it is a condition of accessing publications that users recognise and abide by the legal requirements associated with these rights.

\section{Takedown policy}

If you believe that this document breaches copyright please refer to the University of Manchester's Takedown Procedures [http://man.ac.uk/04Y6Bo] or contact uml.scholarlycommunications@manchester.ac.uk providing relevant details, so we can investigate your claim.

\section{OPEN ACCESS}


Biology and significance of signalling pathways activated by IGF-II

Lynda K Harris and Melissa Westwood

Maternal and Fetal Health Research Centre, University of Manchester, Manchester, M13 9WL, UK

Keywords: fetal growth, placenta, development, myogenesis, vasculogenesis, cancer

Corresponding author: Melissa Westwood, Maternal and Fetal Health Research Centre, University of Manchester, Manchester Academic Health Sciences Centre, St Mary's Hospital, Oxford Road, Manchester, M13 9WL, UK. Tel: 44 (0)161-276-5460; Fax: 44 (0)161-7016971; e-mail: melissa.westwood@manchester.ac.uk 


\begin{abstract}
Insulin-like growth factor-II (IGF-II) affects many aspects of cellular function through its ability to activate several different receptors and consequently, numerous intracellular signalling molecules. Thus, IGF-II is a key regulator of normal fetal development and growth. However, abnormalities in IGF-II function are associated with cardiovascular disease and cancer. Here we review the cellular mechanisms by which IGF-II's physiological and pathophysiological actions are exerted by discussing the involvement of the type 1 and type 2 IGF receptors (IGF1R and IGF2R), the insulin receptor and the downstream MAP kinase, PI3 kinase and G-protein coupled signalling pathways in mediating IGF-II stimulated cellular proliferation, survival, differentiation and migration.
\end{abstract}




\section{Introduction}

IGF-II is a 67-amino acids protein produced by post-translational removal of the $\mathrm{COOH}$ terminal E domain from the precursor molecule, pro-IGF-II [1]. Partial cleavage of the E domain results in big-IGF-II (2 isoforms; $1-104$ or 1-87) which, along with pro-IGF-II, are also found in the circulation [2] Mature IGF-II can itself be processed to generate des(37-40) IGF-II (also known as vesiculin; [3]). Little is known about the signalling properties and function of these IGF-II variants so this review will focus on the actions of the mature protein. IGF-II can interact with a number of cell-surface receptors (Figure 1) but it binds to the type 1 IGF receptor (IGF1R) with highest affinity and therefore it's likely that this receptor mediates much of IGF-II's effect on cellular proliferation, survival, differentiation and migration. However, IGF-I also binds to IGF1R and in general, elicits the same effects with greater potency, which has led to some speculation about the specific purpose of IGF-II. In recent years this has been clarified through the use of receptor inhibitors and a better understanding of the pathways downstream of the type 2 IGF / mannose-6-phosphate receptor (IGF2R) and also, the A isoform of the insulin receptor (IR-A; Figure 1), both of which bind IGF-II with greater affinity than IGF-I. Here we discuss aspects of physiology and pathophysiology that have been attributed to IGF-II.

Type 1 IGF receptor: IGF1R is a heterotetramer with structural homology to the insulin receptor thus in tissues that express both, many of the IGF binding sites are formed as hybrids of the two receptor types [4], though their affinity for IGF-II is similar to that of IGF1R [4]. Activation of IGF1R results in autophosphorylation of tyrosine residues in the intracellular $\beta$ subunits and then, in general, initiation of the PI-3 kinase/AKT or MAP kinase signalling cascades (reviewed in [5-7]).

Insulin receptor: The insulin receptor exists as two isoforms, IR-A and IR-B, depending on the absence or presence of exon 11 splicing [8]. IR-A, but not IR-B, has a high affinity for IGF-II and in fact, binds IGF-II just as well as IGF1R. IR-A is also linked to the same downstream signalling molecules as the classical IGF receptor but IGF-II/IR-A interactions are reported to preferentially activate the MAP kinase pathway [8].

Type 2 IGF receptor: IGF2R is structurally unrelated to either IGF1R or IR as it consists of just a single, primarily extracytoplasmic, polypeptide chain. This receptor binds IGF-II with greater affinity than IGF-I and whilst it does not accept insulin as a ligand [9], it does have high affinity for the sugar mannose-6-phosphate (M-6-P), and can therefore bind lysosomal enzymes and other growth factors and cytokines. Cloning of the type 2 IGF receptor cDNA [10] led to the realization that this receptor was also the cation independent receptor for M-6$\mathrm{P}$; given the well documented role of this receptor in the intracellular transport of lysosomal enzymes, it was suggested that rather than mediating IGF-II effects, it might be important for clearing IGF-II from the circulation. However, although IGF2R contains neither tyrosine kinase activity nor an autophosphorylation site, it does link to G-proteins which provides a mechanism for signal transduction [9].

IGF-II access to all of these receptors is controlled by a family of six highly specific binding proteins (IGFBPs 1-6), though their role in modulating IGF-II bioavailability and function is reviewed elsewhere [11-15].

\section{Role of IGF-II and its receptors in fetal growth}

It is well established that the IGF axis is essential for fetal development and growth. In humans, evidence for the importance of IGF-II comes from the observation that Igf2 is maternally imprinted [16]. Relaxation of imprinting leads to Beckwith-Wiedermann syndrome in which excess IGF-II is associated with fetal overgrowth [17]. The genes for IGF1R, IGF2R and IR are not imprinted although all three receptors are key for normal prenatal growth [18-20]. However, most of the growth disorders associated with perturbations 
in the IGF axis are not due to gene defects and many studies have demonstrated that the correlation between fetal growth restriction (FGR) and decreased IGF-II levels [21-25] commonly occurs in the absence of any apparent mutation. Interestingly, not all studies report a relationship between serum IGF-II concentrations and fetal weight [26;27]. Igf2 and Igf $2 R$ are polymorphic and variants in both are associated with birth weight [19;28], which may account for these conflicting findings. Another possibility is the variation in the level of soluble IGF2R, which is formed by proteolytic cleavage in the transmembrane region of the expressed receptor [29] and is known to inhibit IGF-II's actions [30;31]. This component of the IGF axis is rarely analysed in relation to fetal growth, however one study that IGF-II levels are associated with birth weight only when considered as a molar ratio to soluble IGF2R and that depending on parity, the IGF-II/IGF2R ratio accounted for up to $5 \%$ in birth weight variance [32].

In mice, the gene for IGF-II and that for IGF2R, which is thought to regulate the availability of IGF-II, are reciprocally imprinted [33;34], presenting an attractive mechanism for balancing the needs of mother and fetus during pregnancy [35]. Like humans, perturbations in ligand and receptor expression are associated with altered fetal growth in the mouse. Ablation of the IGF-II gene results in severe in utero growth restriction and neonatal mice which are $40 \%$ smaller than their wild type littermates [36]. In postnatal life, igf2 null animals are always remarkably smaller than their normal littermates, however their growth velocity is unaffected, which has led to the suggestion that IGF-II's role as a growth regulator is principally relevant to fetal life. Elimination of the type 1 IGF receptor accentuates the growth-restricted phenotype (45\% of normal birthweight) and results in perinatal lethality [37] whereas mice in which the Igf $r$ has been ablated have elevated levels of circulating IGFII and are 25-30\% larger than wild type littermates[38;39]. Unlike in humans, a null mutation in the insulin receptor gene has no affect on fetal growth [40].

\section{IGF-II affects fetal growth by influencing placental development and function}

IGF-II null mice and, importantly, mice lacking only the placental-specific transcript of IGFII [41] have small placentas [42]. In contrast, animals carrying a null mutation in Igf $2 r$, like the fetuses with Beckwith-Wiedemann syndrome, exhibit placentomegaly and, unusually [43], these placentas continue to grow right up till birth [38]. Together, these studies suggest that IGF-II may influence fetal growth by promoting normal placental development and function.

In human placenta, IGF-II is expressed by the chorionic villi (cytotrophoblasts, mesodermal core and vascular endothelium) and fetal membranes (amnion and chorion laeve) from early pregnancy [44], though the IGF-II present in the maternal circulation also has a role in regulating events within the placenta [45]. IGF1R is apparent in trophoblast and villous endothelium and stroma [46]. This finding led to the hypothesis that a reduction in the number or distribution of placental type 1 IGF receptors might be a contributing factor in pregnancies complicated by FGR. This is supported by data from a Western blot analysis of such placentas [47], however a study using immunohistochemistry was unable to discern any differences in receptor localization or density [46], and analysis by quantitative PCR detected an increase in expression [48]. Aberrations in the signalling molecules downstream of IGF1R (Figure 2A) could also influence placental, and consequently, fetal growth [45] and decreased expression and / or activation of Akt and members of the MAP kinase pathway in placentas from FGR pregnancies has been described [47;49].

Mice containing null mutations in both the IGF-II and IGF1R genes were more severely growth restricted than those in which only the receptor had been ablated [42]. This, together with the fact that placental weight is reduced in IGF-II deficient mice suggests that not all of IGF-II's effects are mediated through IGF1R; in the human placenta, candidates include 
IGF2R and the insulin receptor, both of which are expressed by trophoblast [50;51], though the distribution of the IR isoforms within placenta has not been documented.

\section{IGF-II influences placental development and function by a number of mechanisms}

Trophoblast turnover: The outer syncytiotrophoblast layer of the human placenta, which is bathed in maternal blood and is therefore crucial as an immune barrier and transporting epithelium, is a terminally differentiated cell that must be renewed and expanded by differentiation and fusion of cells from an underlying cytotrophoblast progenitor layer. Apoptotic elements are continuously shed into the maternal circulation. A role for IGF-II in regulating cytotrophoblast proliferation was implied by an immunohistochemical analysis of first trimester placenta which demonstrated a correlation between IGF-II expression and proliferative activity [52], though we have provided direct evidence using an explant model of first trimester [53] and term [54] human placenta in which IGF-II is supplied to the syncytiotrophoblast surface, mimicking exposure to hormone in the maternal circulation. In these experiments, IGF-II stimulated the proliferation of cells in the underlying cytotrophoblast layer, which suggests the presence of pathways capable of transducing signals from the syncytiotrophoblast to the cytotrophoblast; conceivably this might be achieved either by a syncytioplasmic kinase relay activated by ligand binding at the maternalfacing microvillous membrane, or by transcytosis of ligand with exocytosis at the basal syncytial surface and rebinding to receptor on cytotrophoblast. Other data supporting a role for the maternal IGF axis comes from a study of food-restricted guinea pigs in which maternal IGF-II levels were related to placental structural development[55-59].

The majority of IGF-II's mitogenic actions are thought to be mediated through IGF1R (Figure 2A) and this is certainly supported by the studies on mice with a null mutation in this gene, as these animals have a much more severe phenotype than those lacking either of the ligands. We found that IGF-II-stimulated cytotrophoblast proliferation was reduced in the presence of a specific IGF1R inhibitor [53] however, IGF2R may also have a role in mediating IGF-II's mitogenic effects as proliferation was enhanced in term placental explants exposed to an IGFII analogue, Leu ${ }^{27}$ IGF-II [54]. Leu ${ }^{27}$ IGF-II primarily binds to IGF2R [60] and is commonly used to distinguish between cellular signalling and function initiated by IGF-II/IGF1R versus IGF-II/IGF2R interactions. We have shown, again by using pharmacological inhibitors, that the MAP kinase pathway is responsible for mediating the proliferative effects of IGF-II [53], thus it is interesting to note that through activation of sphingosine kinase and the production of sphingosine-1-phosphate, the ligand for G-protein coupled S1P receptors, IGF2R can also link in to this signalling cascade [61]. Flux through the MAP kinase, and other signalling pathways, is regulated by protein tyrosine phosphatases (PTPs). Although expressed by placenta [62], relatively little is known about their importance in this tissue, though we have recently found that one of the enzymes, SHP-2, is required for IGF-II stimulation of cytotrophoblast proliferation [63].

IGF-II is known to provide a survival signal in many cell systems and recent work suggests that at the maternal-fetal interface also, it may play a role in this context since it can protect both first trimester [53] and term [54] cytotrophoblast from apoptosis. IGF1R is clearly involved in mediating this effect, though downstream, the PI-3 kinase/Akt rather than the MAP kinase pathway seems to be key (Figure 2A) [53]. Again, the contribution of IGF2R must be considered; Leu ${ }^{27}$ IGF-II promoted cytotrophoblast survival however our data indicates that IGF2R also functions as a clearance receptor, since in tissue with reduced IGF2R, IGF-II activity was enhanced thereby suggesting that IGF-II signalling can be redirected through IGF1R [54]. 
Trophoblast migration: Successful implantation and placental development depends on adequate extravillous trophoblast invasion (EVT) of the maternal endometrium and there are several lines of evidence to implicate IGF-II as a mediator of this process. mRNA localization studies have demonstrated abundant IGF-II expression in the trophoblastic columns of the anchoring villi, particularly in those cells at the leading edge of the column [44]. Moreover, in vitro studies have shown that in monolayer wounding [64] or trans-Matrigel barrier assays [65], the migration of these cells is increased in response to IGF-II. Several reports suggest that IGF-II's ability to promote migration is dependent on IGF2R [66;67] and in trophoblast also, Leu ${ }^{27}$ IGF-II and QAYL-Leu ${ }^{27}$ IGF-II, another analogue that is selective for IGF2R, enhanced migration whereas function-blocking IGF2R antibodies were inhibitory [68]. The authors also report that IGF-II signalling through this receptor involves $G_{i}$ proteins and activation of the MAP kinase pathway [68] as well as the Rho kinases, ROCK-I and -II (Figure 2B) [69]. Members of the Rho GTPase family (RhoA and RhoC) are also required for IGF-II stimulation of EVT through IGF1R [69]. There is some controversy about the role of IR-A in mediating IGF-II directed EVT migration, as Shields and colleagues suggest from their work using an IR tyrosine kinase inhibitor, that this receptor is not involved [69], whereas a study using a choriocarcinoma cell model of EVT, found that the actions of IGF-II were reduced in the presence of a different IR inhibitor [70].

Nutrient transport: IGF-II is also a potent metabolic factor and could therefore modulate fetal growth by influencing nutrient transfer across the placenta. IGF-II is known to stimulate both glucose and amino acid uptake by cultured human trophoblast [71-74] and in the guinea pig, maternal administration of IGF-II has been shown to increase placental transport of nutrients to the fetus resulting in enhanced fetal growth $[56 ; 57 ; 75]$. Similar effects were observed when animals were treated with Leu ${ }^{27}$ IGF-II, suggesting that maternal IGF-II promotes, at least in part, nutrient delivery to the fetus via IGF2R [58]. Indeed, rather than a direct affect of IGF-II, enhanced nutrient transfer across an enlarged placenta has been proposed as an explanation for the increased embryo weights noted in the mice null for IGF2R [38]. Correspondingly, deletion of placental IGF-II leads to a reduction in the surface area of the nutrient exchange barrier [41;76], decreased amino acid transfer [77] and consequently, fetal growth restriction.

\section{Role of IGF-II in early cardiac development, myogenesis and vasculogenesis}

IGF-II gene expression has been reported as early as embryonic day 5.5 (E5.5) in the preimplantation mouse blastocyst, where it is localised to the extraembryonic ectoderm and the ectoplacental cone, but not the epiblast [78]. At E6.5, Igf2 transcripts are also expressed in the columnar visceral endoderm, extraembryonic mesoderm, and in trophoblast giant cells. At E7.5, expression is observed in all extraembryonic structures, including the allantois, the amnion, the chorion and the visceral yolk sac. At this time, Igf2 expression is noted in a restricted region of embryonic mesoderm, which at E8.0, extends to include the developing heart, the lateral mesoderm, the head mesenchyme, and the lining of the foregut. The functional importance of IGF-II signalling during cardiac development was highlighted when the differentiation potential of murine embryonic stem (ES) cells expressing reduced levels of IGF-II was investigated: the absence of Igf 2 severely impaired the expression of mesoderm markers, and the subsequent formation of mesoderm derivatives including cardiomyocytes and muscle fibers [79]. In addition, IGF-II synthesised by the epicardium is required to activate MAP kinase signalling pathway and induce cardiomyocyte proliferation in the developing mouse heart from E10.5-E14.5. Igf2 null mice exhibit significantly decreased rates of cardiomyocyte proliferation in the ventricular wall at E11.5, resulting in ventricular wall hypoplasia [80]. IGF-II signalling also regulates differentiation of adult myoblasts, inducing exit from the cell cycle, expression of muscle-specific genes and formation of multinucleated 
myotubes. Initiation of myogenesis is achieved by an IGF-II-mediated increase in ERK5 phosphorylation and kinase activity, translocation of ERK5 to the nucleus and myogenic E box promoter activity (Figure 2B) [81].

The IGF2R signalling axis also regulates postnatal vasculogenesis by controlling homing of endothelial progenitor cells (EPC). EPC isolated from human placental cord blood express high levels IGF2R, and IGF-II signalling through IGF2R, but not IGF1R, increased EPC migration, invasion, adhesion to fibrinogen and MMP-9 secretion in vitro [82]. Signalling was mediated via the $G$ protein subunit $G(i)$ and phospholipase-C $\beta_{2}\left(P L C \beta_{2}\right)$, leading to an increase in intracellular $\mathrm{Ca}^{2+}$ (Figure 2B) [82]. IGF-II promoted recruitment of murine bone marrow mononuclear cells (MBMMC) and neo-vascularisation in a mouse Matrigel plug assay, and increased the number of MBMMC incorporated into the capillaries in a mouse model of hindlimb ischemia [82].

\section{IGF-II signalling in cardiovascular development and disease}

Cardiomyocyte apoptosis is one of the primary causes of cardiovascular pathology following myocardial infarction. The adult cardiomyocyte cannot proliferate, thus the signalling pathways that regulate cell survival have been extensively studied. IGF-I signalling through IGF1R promotes physiological cardiac growth and function, and improves cardiac output after myocardial infarction by stimulating contractility and tissue remodelling [83]. In contrast, evidence from cell culture studies and animal models is mixed, suggesting that IGFII signalling can induce hypertrophy, extracellular matrix remodelling and apoptosis, but also that IGF-II overexpression can enhance cardiomyocyte survival.

Treatment of the cardiomyoblast cell line H9c2 with angiotensin-II upregulated IGF-II and IGF2R expression, induced activation of caspase- 8 and -9 , and increased cardiomyoblast apoptosis via an IGF2R-dependent mechanism [84]. Similarly, Leu ${ }^{27}$ IGF-II has been shown to enhance angiotensin-II induced $\mathrm{H} 9 \mathrm{c} 2$ cell apoptosis, mediated by the interaction of IGF2R with the $G$ protein subunit $G \alpha q$ and phosphorylation of $P L C \beta_{3}$, leading to increased caspase activation and DNA fragmentation (Figure 2B) [85]. These findings are mirrored in neonatal rat ventricular myocytes following knockdown of IGF1R expression, where IGF-II treatment induced phosphorylation of Akt, increased caspase-3 activation and induced apoptosis [86]. Interestingly, Leu ${ }^{27}$ IGF-II treatment also increased apoptosis in cells lacking IGF1R, but did so in the absence of Akt phosphorylation. Instead, activation of Goq and calcineurin lead to translocation of the pro-apoptotic protein Bad to the mitochondria, cytochrome c release and activation of caspase-3 and -9 (Figure 2B) [86].

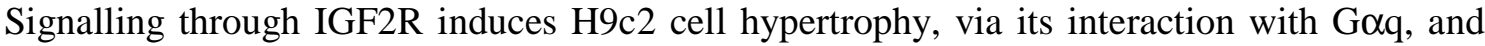
phosphorylation of protein kinase $\mathrm{C}-\alpha$ and calcium/calmodulin-dependent protein kinase II, leading to increased expression of the cardiac hypertrophy markers atrial natriuretic peptide and brain natriuretic peptide (Figure 2B) [87]. IGF-II signalling through IGF2R also promoted extracellular matrix catabolism in these cells, by increasing the expression of matrix metalloproteinase-9, urokinase plasminogen activator and tissue plasminogen activator, and by reducing expression of tissue inhibitor of metalloproteinases-2 [88].

In vivo, rats subjected to ligation of the abdominal aorta exhibit increased expression of IGFII and IGF2R in the left ventricle, and display hypertension and enhanced myocyte apoptosis [84]. As expression of IGF2R is increased in areas of infarcted human myocardium [87], and elevated expression is maintained in the resulting scar tissue [88], signalling through the IGF2R may enhance pathological myocardial apoptosis and hypertrophy, exacerbating the existing damage.

In contrast to the studies cited above, transduction of cardiomyocytes with an adenoviral vector encoding IGF-II significantly reduced apoptosis induced by heat shock or ischemia- 
reoxygenation [89]. Moreover, downregulation of the IGF-II clearance receptor IGF2R in neonatal rat cardiac myocytes reduced cell susceptibility to hypoxia- and tumour necrosis factor-induced apoptosis [90]. These findings suggest that IGF-II signalling through IGF1R can enhance cardiomyocyte survival.

\section{IGF-II signalling in cancer}

Aberrant autocrine and paracrine IGF-II signalling, leading to enhancement of cell proliferation and resistance to apoptosis, has long been implicated in the initiation and progression of tumour growth [91]. Epigenetic alterations, such as loss of DNA imprinting, occur in cancer at least as commonly as genetic mutations. The majority of imprinted genes exist in clusters, and their expression is regulated by the methylation status of CpG-rich ciselements, known as differently methylated regions (DMRs) [92]. The DMRs are differentially methylated on $\mathrm{CpG}$ sites by DNA methyltransferases, depending on the parental origin of the allele [92]. Igf2 is an example of an imprinted gene; loss of imprinting (LOI) of the normally silent maternal allele of $I g f 2$ leads to overexpression of IGF-II protein and an increased risk of malignancy.

Colon cancer: Biallelic expression of $I g f 2$ in a mouse model of intestinal neoplasia induced intestinal adenoma formation, elongation of intestinal crypts and an increased population of epithelial progenitor cells in the mucosa [93]. This increase in mucosal epithelial progenitor cells is also observed in the normal gut mucosa of humans presenting with colon-specific LOI of Igf2 [93], leading to an elevated risk of colorectal cancer for affected individuals [94]. Similar findings were observed when azoxymethane was used to induce the formation of premalignant aberrant crypt foci in mice with Igf2 LOI: expression of proliferation-related genes in the intestinal crypts was increased, leading to enhanced tumour formation [95]. Blockade of the IGF1R signalling pathway using the competitive inhibitor NVP-AEW541 decreased expression of proliferation-related genes and significantly reduced pre-malignant aberrant crypt foci formation [95]. Using mouse embryo fibroblast cell lines from Igf2 LOI and wild type embryos, the authors also demonstrated that LOI cells showed an enhanced sensitivity to IGF-II signalling. Low doses of IGF-II induced sustained Akt activation in LOI cells, whereas cells from wild type embryos exhibited only a transient increase in Akt activation [95]. IGF2R and insulin receptor expression were also increased in these cells.

Breast cancer: Female transgenic mice engineered to exhibit enhanced IGF-II expression in the mammary gland displayed an increased incidence of aggressive, metastatic, mammary tumours [96], implicating chronic IGF-II signalling as a tumourigenic stimulus. As predicted, when these animals were crossed with transgenic mice overexpressing IGF2R, their offspring exhibited a significant delay in the onset of mammary tumour formation and reduced tumour burden [97]. Biallelic IGF-II expression has been observed in human breast cancer samples: one study reported LOI in $67 \%$ of benign lesions and $60 \%$ of malignant lesions, whereas all control samples displayed normal IGF-II imprinting [98]. However, only 3 benign and 5 malignant tissue samples were analysed, so these data must be interpreted with caution. ProIGF-II has been shown to promote the survival of the MCF7 breast cancer cell line by activating PI3K/Akt signalling and upregulating the expression of the anti-apoptotic proteins $\mathrm{Bcl}-2$ and $\mathrm{Bcl}-\mathrm{X}_{\mathrm{L}}$ [99]. Mature IGF-II can also promote breast cancer progression by activating estrogen receptor- $\alpha(E R-\alpha)$ and ER- $\beta$ in the absence of estrogen. In breast cancer cells, IGF-II binding to IGF1R and the insulin receptor induced translocation of ER- $\alpha$ and ER- $\beta$ to the mitochondria, facilitating activation of cell survival pathways [100]. 
Pancreatic cancer: Transgenic mice expressing the SV40 large T-antigen (Tag) under the control of the insulin gene regulatory region develop hyperplasia within the islets of Langerhans, followed by the occurrence of pancreatic tumours. Increased IGF-II expression, due to LOI of the Igf 2 gene, is observed in this population of hyperproliferative $\beta$ cells [101]. When crossed with Igf2 null mice, Tag mice displayed a dramatically reduced tumour burden and had a five-fold higher incidence of tumour cell apoptosis [101], again highlighting both the proliferative and pro-survival effects of IGF-II signalling. Interestingly, Tag mice that carried a disruption in either the paternal or maternal $I g f 2$ allele developed tumours of a similar size and histology to wild type Tag mice, indicating that both the developmentally expressed paternal allele or the inactive maternal allele could contribute to tumour development [102]. In humans, evidence of a role for IGF-II in pancreatic cancer is mixed: a nested case-control study has shown no correlation between increased serum concentration of IGF-II and increased risk of pancreatic cancer [103], and no change in IGF-II mRNA expression was observed in human pancreatic cancer samples, despite biallelic Igf2 expression [104]. However, a recent study has reported hypermethylation of the Igf2 DMR2 in insulinomas, which was associated with LOI and overexpression of IGF-II at the mRNA and protein level [105].

Lung cancer: Immortalised mouse embryonic fibroblasts from wild-type, and but not integrin $\alpha_{11}$ null mice, significantly enhanced the growth of A549 human lung adenocarcinoma cells, when co-implanted into immune deficient mice [106]. Gene profiling of the resulting tumours revealed a 100-fold reduction in IGF-II mRNA expression in tumours formed in mice injected with the integrin $\alpha 11$ null fibroblasts [106]. siRNA-mediated knockdown of fibroblast IGF-II expression reduced the growth of A549 tumours to a similar extent, suggesting that in this system, the growth promoting effects of stromal fibroblasts were (i) mediated by the paracrine actions of IGF-II and (ii) dependent on fibroblast integrin $\alpha 11$ expression [106].

Brain tumours: IGF-II is overexpressed in a subset of high-grade glioblastomas that lack amplification or overexpression of the EGF receptor, and are characterised by poor survival [107]. Tumours overexpressing IGF-II were highly proliferative, exhibited enhanced Akt phosphorylation and displayed PTEN loss. IGF-II signalling through IGF1R and PI3-kinase regulatory subunit 3 recapitulated the tumourigenic effects of EGF and promoted the growth of glioblastoma-derived neurospheres in vitro (Figure 2B) [107].

Other cancers: As mentioned above, individuals with Beckwith-Wiedemann syndrome (BWS) exhibit biallelic Igf2 expression, along with aberrant expression of p57, CDKN1C, H19, and LIT1, and have an increased risk of developing childhood cancers [17]. Approximately 5-10\% of BWS patients develop embryonal tumours, including Wilms' tumour of the kidney, but they are also at increased risk of adrenocortical carcinoma, hepatoblastoma and rhabdomyosarcoma [17]. Wilms' tumour is associated with defects in the Wt1 gene, which encodes a transcriptional repressor of $I g f 2$, and with mutations in the 11 p15.5 region that alter Igf2 imprinting. As such, biallelic Igf 2 expression is observed in the majority of pathological cases [108]. Biallelic IGF-II expression has also been reported in human cases of testicular germ cell tumours [109], choriocarcinoma [110], primary lung cancers including adenocarcinoma, squamous cell carcinoma, large and small cell carcinoma [111], and cervical carcinomas [112], uterine leiomyosarcoma [113] and endometrial cancer [114]. 


\section{IGF2R signalling in cancer}

The tumour suppressor function of the IGF2R was first demonstrated by O'Gorman et al., who showed that down-regulation of IGF2R expression in JEG-3 choriocarcinoma cells enhanced proliferation in vitro, and increased tumor growth rate in vivo [115]. Conversely, IGF2R overexpression reduced JEG-3 cell proliferation in vitro, and decreased tumor growth in nude mice [116]. IGF2R overexpression did not alter endogenous IGF-II production, or secretion of the IGF2R ligands procathepsin $\mathrm{D}$ and $\mathrm{L}$, but did promote secretion and activation of latent TGF- $\beta 1$. Overexpression of a soluble form of the receptor dramatically reduced tumour cell growth in vitro and in vivo, but did not alter the level of TGF- $\beta 1$ [116]. These data suggest that increased levels of soluble IGF2R inhibit cell proliferation.

Unlike its murine homologue, human $\operatorname{Ig} f 2 r$ exhibits biallelic expression, [117;118], although a few individuals exclusively express the maternal allele [119]. Mutations in $I g f 2 r$, or loss of heterozygosity at the 6q26-27 locus where I $g f 2 r$ resides, lead to reduced IGF2R expression and increased circulating concentrations of IGF-II. Loss of biallelic $I g f 2 r$ expression has been reported in cancers of the breast, liver, prostate, lung, adrenal gland, head, neck and endometrium [120] and in the kidneys of Wilms tumor patients [121]. Loss of heterozygosity proximal to the $I g f 2 r$ locus is also predictive of the presence of disseminated tumour cells in the bone marrow of ovarian cancer patients, before and after chemotherapy [122].

\section{IR-A signalling in cancer}

Ligation of IR-A by IGF-II initiates a proliferative response [123], and abberant IR-A signalling has been implicated in a number of diseases, including cancer (Reviewed in [8]). IGF-II signalling through IR-A has also been shown to induce differential expression of genes involved in signal transduction, cell cycle, metabolism, angiogenesis and adhesion, when compared to insulin signalling [124].

IR-A is the predominant IR isoform expressed by carcinomas of the breast, colon and lung [123], and the relative abundance of IR-A is increased in thyroid cancer, compared to normal thyroid tissue [125]. Activation of IR by IGF-II in human breast cancer cell lines stimulated proliferation, with IGF-II exhibiting $63 \%$ of the potency of insulin. In contrast, IGF-II signalling through IR in non-malignant human breast cells was less than $1 \%$ as potent as insulin [126]. IGF-II is also reported to be a more potent stimulator of SKUT-1 leiomyosarcoma cell migration than insulin, a cell line that expresses IR-A but not IGF1R [127]. However, siRNA-mediated knockdown of IR-A in SW480 human colon adenocarcinoma cells increased viability and enhanced IGF1R activation by IGF-II [128], suggesting that IGF-II bioactivity is mediated most effectively by IGF1R.

\section{Summary}

In summary, IGF-II is a critical mediator of cell fate, regulating normal embryonic development and placental function, but also inducing aberrant proliferation and cell survival in cancer and cardiovascular disease. By understanding in more detail how the actions of IGFII are regulated, either through genetic, epigenetic or posttranslational modifications, downstream signaling cascasdes, or via its interactions with IGF binding proteins or the IGF$2 \mathrm{R}$, we will be better placed to combat its pathophysiological effects. 
Declarations of Interest: LKH is supported by a BBSRC David Phillips Research Fellowship. The Maternal and Fetal Health Research Centre is supported by the Manchester Academic Health Sciences Centre and the Greater Manchester Comprehensive Local Research Network. 


\section{References}

[1] Duguay SJ, Jin Y, Stein J, Duguay AN, Gardner P, Steiner DF: Posttranslational processing of the insulin-like growth factor-2 precursor. Analysis of O-glycosylation and endoproteolysis. J Biol Chem 1998;273:18443-18451.

[2] Marks AG, Carroll JM, Purnell JQ, Roberts CT, Jr.: Plasma distribution and signaling activities of IGF-II precursors. Endocrinology 2011;152:922-930.

[3] Buchanan CM, Phillips AR, Cooper GJ: A novel two-chain IGF-II-derived peptide from purified beta-cell granules. Growth Horm IGF Res 2010;20:360366.

[4] Kasuya J, Paz IB, Maddux BA, Goldfine ID, Hefta SA, Fujita-Yamaguchi Y: Characterization of human placental insulin-like growth factor-I/insulin hybrid receptors by protein microsequencing and purification. Biochemistry 1993;32:13531-13536.

[5] Riedemann J, Macaulay VM: IGF1R signalling and its inhibition. Endocr Relat Cancer 2006;13 Suppl 1:S33-S43.

[6] Laviola L, Natalicchio A, Giorgino F: The IGF-I signaling pathway. Curr Pharm Des 2007;13:663-669.

[7] Tao Y, Pinzi V, Bourhis J, Deutsch E: Mechanisms of disease: signaling of the insulin-like growth factor 1 receptor pathway--therapeutic perspectives in cancer. Nat Clin Pract Oncol 2007;4:591-602.

[8] Belfiore A, Frasca F, Pandini G, Sciacca L, Vigneri R: Insulin receptor isoforms and insulin receptor/insulin-like growth factor receptor hybrids in physiology and disease. Endocr Rev 2009;30:586-623.

[9] El-Shewy HM, Luttrell LM: Insulin-like growth factor-2/mannose-6 phosphate receptors. Vitam Horm 2009;80:667-697.

[10] Morgan DO, Edman JC, Standring DN, Fried VA, Smith MC, Roth RA, Rutter WJ: Insulin-like growth factor II receptor as a multifunctional binding protein. Nature 1987;329:301-307.

[11] Duan C, Xu Q: Roles of insulin-like growth factor (IGF) binding proteins in regulating IGF actions. Gen Comp Endocrinol 2005;142:44-52.

[12] Bach LA, Headey SJ, Norton RS: IGF-binding proteins--the pieces are falling into place. Trends Endocrinol Metab 2005;16:228-234.

[13] Silha JV, Murphy LJ: Insulin-like growth factor binding proteins in development. Adv Exp Med Biol 2005;567:55-89.

[14] Forbes K, Westwood M: The IGF axis and placental function. a mini review. Horm Res 2008;69:129-137. 
[15] Holly J, Perks C: The role of insulin-like growth factor binding proteins. Neuroendocrinology 2006;83:154-160.

[16] Giannoukakis N, Deal C, Paquette J, Goodyer CG, Polychronakos C: Parental genomic imprinting of the human IGF2 gene. Nat Genet 1993;4:98-101.

[17] Ward A: Beckwith-Wiedemann syndrome and Wilms' tumour. Mol Hum Reprod 1997;3:157-168.

[18] Abuzzahab MJ, Schneider A, Goddard A, Grigorescu F, Lautier C, Keller E, Kiess W, Klammt J, Kratzsch J, Osgood D, Pfaffle R, Raile K, Seidel B, Smith RJ, Chernausek SD: IGF-I receptor mutations resulting in intrauterine and postnatal growth retardation. N Engl J Med 2003;349:2211-2222.

[19] Kaku K, Osada H, Seki K, Sekiya S: Insulin-like growth factor 2 (IGF2) and IGF2 receptor gene variants are associated with fetal growth. Acta Paediatr 2007;96:363-367.

[20] Taylor SI: Lilly Lecture: molecular mechanisms of insulin resistance. Lessons from patients with mutations in the insulin-receptor gene. Diabetes 1992;41:1473-1490.

[21] Bennett A, Wilson DM, Liu F, Nagashima R, Rosenfeld RG, Hintz RL: Levels of insulin-like growth factors I and II in human cord blood. J Clin Endocrinol Metab 1983;57:609-612.

[22] Leger J, Oury JF, Noel M, Baron S, Benali K, Blot P, Czernichow P: Growth factors and intrauterine growth retardation. I. Serum growth hormone, insulinlike growth factor (IGF)-I, IGF-II, and IGF binding protein 3 levels in normally grown and growth-retarded human fetuses during the second half of gestation. Pediatr Res 1996;40:94-100.

[23] Giudice LC, de-Zegher F, Gargosky SE, Dsupin BA, de-las Fuentes L, Crystal RA, Hintz RL, Rosenfeld RG: Insulin-like growth factors and their binding proteins in the term and preterm human fetus and neonate with normal and extremes of intrauterine growth. J Clin Endocrinol Metab 1995;80:1548-1555.

[24] Westwood M, Gibson JM, Sooranna SR, Ward S, Neilson JP, Bajoria R: Genes or placenta as modulator of fetal growth: evidence from the insulin-like growth factor axis in twins with discordant growth. Mol Hum Reprod 2001;7:387-395.

[25] Bajoria R, Gibson JM, Ward S, Sooranna SR, Neilson JP, Westwood M: Placental regulation of IGF axis in monochorionic twins with chronic twin-twin transfusion syndrome. J Clin Endocrinol Metab 2001;86:3150-3156.

[26] Klauwer D, Blum WF, Hanitsch S, Rascher W, Lee PD, Kiess W: IGF-I, IGFII, free IGF-I and IGFBP-1, -2 and -3 levels in venous cord blood: relationship to birthweight, length and gestational age in healthy newborns. Acta Paediatr 1997;86:826-833.

[27] Osorio M, Torres J, Moya F, Pezzullo J, Salafia C, Baxter R, Schwander J, Fant M: Insulin-like growth factors (IGFs) and IGF binding proteins-1, -2, and 
$\mathbf{- 3}$ in newborn serum: relationships to fetoplacental growth at term. Early Hum Dev 1996;46:15-26.

[28] Adkins RM, Somes G, Morrison JC, Hill JB, Watson EM, Magann EF, Krushkal J: Association of birth weight with polymorphisms in the IGF2, H19, and IGF2R genes. Pediatr Res 2010;68:429-434.

[29] Nissley P, Kiess W, Sklar M: Developmental expression of the IGF-II/mannose 6-phosphate receptor. Mol Reprod Dev 1993;35:408-413.

[30] Scott CD, Ballesteros M, Madrid J, Baxter RC: Soluble insulin-like growth factor-II/mannose 6-P receptor inhibits deoxyribonucleic acid synthesis in cultured rat hepatocytes. Endocrinology 1996;137:873-878.

[31] Scott CD, Weiss J: Soluble insulin-like growth factor II/mannose 6-phosphate receptor inhibits DNA synthesis in insulin-like growth factor II sensitive cells. J Cell Physiol 2000;182:62-68.

[32] Ong K, Kratzsch J, Kiess W, Costello M, Scott C, Dunger D: Size at birth and cord blood levels of insulin, insulin-like growth factor I (IGF-I), IGF-II, IGFbinding protein-1 (IGFBP-1), IGFBP-3, and the soluble IGF-II/mannose-6phosphate receptor in term human infants. The ALSPAC Study Team. Avon Longitudinal Study of Pregnancy and Childhood. J Clin Endocrinol Metab 2000;85:4266-4269.

[33] DeChiara TM, Robertson EJ, Efstratiadis A: Parental imprinting of the mouse insulin-like growth factor II gene. Cell 1991;64:849-859.

[34] Stoger R, Kubicka P, Liu CG, Kafri T, Razin A, Cedar H, Barlow DP: Maternal-specific methylation of the imprinted mouse Igf $2 \mathrm{r}$ locus identifies the expressed locus as carrying the imprinting signal. Cell 1993;73:61-71.

[35] Haig D, Graham C: Genomic imprinting and the strange case of the insulin-like growth factor-II receptor. Cell 1991;64:1045-1046.

[36] DeChiara TM, Efstratiadis A, Robertson EJ: A growth-deficiency phenotype in heterozygous mice carrying an insulin-like growth factor II gene disrupted by targeting. Nature 1990;345:78-80.

[37] Liu JP, Baker J, Perkins AS, Robertson EJ, Efstratiadis A: Mice carrying null mutations of the genes encoding insulin-like growth factor I (Igf-1) and type 1 IGF receptor (Igf1r). Cell 1993;75:59-72.

[38] Lau MMH, Stewart CEH, Liu Z, Bhatt H, Rotwein P, Stewart CL: Loss of the imprinted IGF2/cation-independent mannose 6-phosphate receptor results in fetal overgrowth and perinatal lethality. Genes Dev 1994;8:2953-2963.

[39] Ludwig T, Eggenschwiler J, Fisher P, D'Ercole AJ, Davenport ML, Efstratiadis A: Mouse mutants lacking the type 2 IGF receptor (IGF2R) are rescued from perinatal lethality in Igf2 and Igf1r null backgrounds. Dev Biol 1996;177:517535. 
[40] Joshi RL, Lamothe B, Cordonnier N, Mesbah K, Monthioux E, Jami J, Bucchini D: Targeted disruption of the insulin receptor gene in the mouse results in neonatal lethality. EMBO J 1996;15:1542-1547.

[41] Constancia M, Hemberger M, Hughes J, Dean W, Ferguson-Smith A, Fundele R, Stewart F, Kelsey G, Fowden A, Sibley CP, Reik W: Placental-specific IGF2 is a mafor modulator of placental and fetal growth. Nat Med 2002;417:945-948.

[42] Baker J, Liu JP, Robertson EJ, Efstratiadis A: Role of insulin-like growth factors in embryonic and postnatal growth. Cell 1993;75:73-82.

[43] McLaren A: Placental weight loss in late pregnancy. J Reprod Fertil 1965;9:343-346.

[44] Han VKM, Bassett N, Walton J, Challis JR: The expression of insulin-like growth factor (IGF) and IGF-binding protein (IGFBP) genes in the human placenta and membranes: evidence for IGF-IGFBP interactions at the fetomaternal interface. J Clin Endocrinol Metab 1996;81:2680-2693.

[45] Forbes K, Westwood M: Maternal growth factor regulation of placental development and fetal growth. J Endocrinol 2010;207:1-16.

[46] Holmes R, Porter H, Newcomb B, Holly JM, Soothill P. An immunohistochemicalstudy of type 1 insulin-like growth factor receptors in the placentae of pregnancies with appropriately or growth restricted fetuses. Placenta 20, 325-330. 99.

[47] Laviola L, Perrini S, Belsanti G, Natalicchio A, Montrone C, Leonardini A, Vimercati A, Scioscia M, Selvaggi L, Giorgino R, Greco P, Giorgino F: Intrauterine growth restriction in humans is associated with abnormalities in placental insulin-like growth factor signaling. Endocrinology 2005;146:14981505.

[48] bu-Amero SN, Ali Z, Bennett P, Vaughan JI, Moore GE: Expression of the insulin-like growth factors and their receptors in term placentas: a comparison between normal and IUGR births. Mol Reprod Dev 1998;49:229-235.

[49] Street ME, Viani I, Ziveri MA, Volta C, Smerieri A, Bernasconi S: Impairment of insulin receptor signal transduction in placentas of intra-uterine growthrestricted newborns and its relationship with fetal growth. Eur J Endocrinol 2011;164:45-52.

[50] Rebourcet R, de CF, Deborde S, Willeput J, Ferre F: Differential distribution of binding sites for 125I-insulin-like growth factor II on trophoblast membranes of human term placenta. Biol Reprod 1998;58:37-44.

[51] Desoye G, Hartmann M, Blaschitz A, Dohr G, Hahn T, Kohnen G, Kaufmann $P$ : Insulin receptors in syncytiotrophoblast and fetal endothelium of human placenta. Immunohistochemical evidence for developmental changes in distribution pattern. Histochemistry 1994;101:277-285. 
[52] Thomsen BM, Clausen HV, Larsen LG, Nurnberg L, Ottesen B, Thomsen HK: Patterns in expression of insulin-like growth factor-II and of proliferative activity in the normal human first and third trimester placenta demonstrated by non-isotopic in situ hybridization and immunohistochemical staining for MIB-1. Placenta 1997;18:145-154.

[53] Forbes K, Westwood M, Baker PN, Aplin JD: Insulin-like growth factor-I and II regulate the life cycle of trophoblast in the developing human placenta. Am J Physiol Cell Physiol 2008;294:C1313-C1322.

[54] Harris LK, Crocker IP, Baker PN, Aplin JD, Westwood M: IGF2 actions on trophoblast in human placenta are regulated by the insulin-like growth factor 2 receptor, which can function as both a signaling and clearance receptor. Biol Reprod 2011;84:440-446.

[55] Roberts CT, Sohlstrom A, Kind KL, Grant PA, Earl RA, Robinson JS, Khong TY, Owens PC, Owens JA: Altered placental structure induced by maternal food restriction in guinea pigs: a role for circulating IGF-II and IGFBP-2 in the mother? Placenta 2001;22 Suppl A:S77-S82.

[56] Sferruzzi-Perri AN, Owens JA, Pringle KG, Robinson JS, Roberts CT: Maternal insulin-like growth factors-I and -II act via different pathways to promote fetal growth. Endocrinology 2006;147:3344-3355.

[57] Sferruzzi-Perri AN, Owens JA, Standen P, Taylor RL, Heinemann GK, Robinson JS, Roberts CT: Early treatment of the pregnant guinea pig with IGFs promotes placental transport and nutrient partitioning near term. Am J Physiol Endocrinol Metab 2007;292:E668-E676.

[58] Sferruzzi-Perri AN, Owens JA, Standen P, Roberts CT: Maternal insulin-like growth factor-II promotes placental functional development via the type 2 IGF receptor in the guinea pig. Placenta 2008;29:347-355.

[59] Pringle KG, Roberts CT: New light on early post-implantation pregnancy in the mouse: roles for insulin-like growth factor-II (IGF-II)? Placenta 2007;28:286-297.

[60] Forbes BE, Hartfield PJ, McNeil KA, Surinya KH, Milner SJ, Cosgrove LJ, Wallace JC: Characteristics of binding of insulin-like growth factor (IGF)-I and IGF-II analogues to the type 1 IGF receptor determined by BIAcore analysis. Eur J Biochem 2002;269:961-968.

[61] El-Shewy HM, Lee MH, Obeid LM, Jaffa AA, Luttrell LM: The insulin-like growth factor type 1 and insulin-like growth factor type 2/mannose-6phosphate receptors independently regulate ERK1/2 activity in HEK293 cells. J Biol Chem 2007;282:26150-26157.

[62] Norris K, Norris F, Kono DH, Vestergaard H, Pedersen O, Theofilopoulos AN, Moller NP: Expression of protein-tyrosine phosphatases in the major insulin target tissues. FEBS Lett 1997;415:243-248. 
[63] Forbes K, West G, Garside R, Aplin JD, Westwood M: The protein-tyrosine phosphatase, SRC homology-2 domain containing protein tyrosine phosphatase-2, is a crucial mediator of exogenous insulin-like growth factor signaling to human trophoblast. Endocrinology 2009;150:4744-4754.

[64] Irving JA, Lala PK: Functional role of cell surface integrins on human trophoblast cell migration: regulation by TGF-beta, IGF-II, and IGFBP-1. Exp Cell Res 1995;217:419-427.

[65] Hamilton GS, Lysiak JJ, Han VKM, Lala PK: Autocrine-paracrine regulation of human trophoblast invasiveness by insulin-like growth factor (IGF)-II and IGF-binding protein (IGFBP)-1. Exp Cell Res 1998;244:147-156.

[66] Minniti CP, Kohn EC, Grubb JH, Sly WS, Oh Y, Muller HL, Rosenfeld RG, Helman LJ: The insulin-like growth factor II (IGF-II)/mannose 6-phosphate receptor mediates IGF-II-induced motility in human rhabdomyosarcoma cells. J Biol Chem 1992;267:9000-9004.

[67] Volpert O, Jackson D, Bouck N, Linzer DI: The insulin-like growth factor-II / mannose 6-phosphate receptor is required for proliferin-induced angiogenesis. Endocrinology 1996;137:3871-3876.

[68] McKinnon T, Chakraborty C, Gleeson LM, Chidiac P, Lala PK: Stimulation of human extravillous trophoblast migration by IGF-II is mediated by IGF type 2 receptor involving inhibitory $G$ protein(s) and phosphorylation of MAPK. J Clin Endocrinol Metab 2001;86:3665-3674.

[69] Shields SK, Nicola C, Chakraborty C: Rho guanosine 5'-triphosphatases differentially regulate insulin-like growth factor I (IGF-I) receptor-dependent and -independent actions of IGF-II on human trophoblast migration. Endocrinology 2007;148:4906-4917.

[70] Diaz LE, Chuan YC, Lewitt M, Fernandez-Perez L, Carrasco-Rodriguez S, Sanchez-Gomez M, Flores-Morales A: IGF-II regulates metastatic properties of choriocarcinoma cells through the activation of the insulin receptor. Mol Hum Reprod 2007;13:567-576.

[71] Kniss DA, Shubert PJ, Zimmerman PD, Landon MB, Gabbe SG: Insulin-like growth factors. Their regulation of glucose and amino acid transport in placental trophoblasts isolated from first-trimester chorionic villi. J Reprod Med 1994;39:249-256.

[72] Karl PI: Insulin-like growth factor-I stimulates amino acid uptake by the cultured human placental trophoblast. J Cell Physiol 1995;165:83-88.

[73] Yu J, Iwashita M, Kudo Y, Takeda Y: Phosphorylated insulin-like growth factor (IGF)-binding protein-1 (IGFBP-1) inhibits while non-phosphorylated IGFBP-1 stimulated IGF-I induced amino acid uptake by cultured trophoblast cells. Growth Hormone \& IGF Research 1998;8:65-70.

[74] Fang J, Mao D, Smith CH, Fant ME: IGF regulation of neutral amino acid transport in the BeWo choriocarcinoma cell line (b30 clone): evidence for MAP 
kinase-dependent and MAP kinase-independent mechanisms. Growth Horm IGF Res 2006;16:318-325.

[75] Sferruzzi-Perri AN, Owens JA, Standen P, Taylor RL, Robinson JS, Roberts CT: Early pregnancy maternal endocrine insulin-like growth factor I programs the placenta for increased functional capacity throughout gestation.

Endocrinology 2007;148:4362-4370.

[76] Sibley CP, Coan PM, Ferguson-Smith A, Dean W, Hughes J, Smith P, Reik W, Burton GJ, Fowden A, Constancia M: Placental-specific insulin-like growth factor 2 (igf2) regulates the diffusional exchange characteristics of the mouse placenta. Proc Natl Acad Sci USA 2004;101:8204-8208.

[77] Sferruzzi-Perri AN, Vaughan OR, Coan PM, Suciu MC, Darbyshire R, Constancia M, Burton GJ, Fowden AL: Placental-specific igf 2 deficiency alters developmental adaptations to undernutrition in mice. Endocrinology 2011;152:3202-3212.

[78] Lee JE, Pintar J, Efstratiadis A: Pattern of the insulin-like growth factor II gene expression during early mouse embryogenesis. Development 1990;110:151-159.

[79] Morali OG, Jouneau A, McLaughlin KJ, Thiery JP, Larue L: IGF-II promotes mesoderm formation. Dev Biol 2000;227:133-145.

[80] Li P, Cavallero S, Gu Y, Chen TH, Hughes J, Hassan AB, Bruning JC, Pashmforoush M, Sucov HM: IGF signaling directs ventricular cardiomyocyte proliferation during embryonic heart development. Development 2011;138:1795-1805.

[81] Carter EJ, Cosgrove RA, Gonzalez I, Eisemann JH, Lovett FA, Cobb LJ, Pell JM: MEK5 and ERK5 are mediators of the pro-myogenic actions of IGF-2. J Cell Sci 2009;122:3104-3112.

[82] Maeng YS, Choi HJ, Kwon JY, Park YW, Choi KS, Min JK, Kim YH, Suh PG, Kang KS, Won MH, Kim YM, Kwon YG: Endothelial progenitor cell homing: prominent role of the IGF2-IGF2R-PLCbeta2 axis. Blood 2009;113:233-243.

[83] Ren J, Samson WK, Sowers JR: Insulin-like growth factor I as a cardiac hormone: physiological and pathophysiological implications in heart disease. $\mathrm{J}$ Mol Cell Cardiol 1999;31:2049-2061.

[84] Lee SD, Chu CH, Huang EJ, Lu MC, Liu JY, Liu CJ, Hsu HH, Lin JA, Kuo WW, Huang CY: Roles of insulin-like growth factor II in cardiomyoblast apoptosis and in hypertensive rat heart with abdominal aorta ligation. Am J Physiol Endocrinol Metab 2006;291:E306-E314.

[85] Chen RJ, Wu HC, Chang MH, Lai CH, Tien YC, Hwang JM, Kuo WH, Tsai FJ, Tsai CH, Chen LM, Huang CY, Chu CH: Leu27IGF2 plays an opposite role to IGF1 to induce H9c2 cardiomyoblast cell apoptosis via Galphaq signaling. J Mol Endocrinol 2009;43:221-230. 
[86] Chu CH, Tzang BS, Chen LM, Liu CJ, Tsai FJ, Tsai CH, Lin JA, Kuo WW, Bau DT, Yao CH, Huang CY: Activation of insulin-like growth factor II receptor induces mitochondrial-dependent apoptosis through $G($ alpha)q and downstream calcineurin signaling in myocardial cells. Endocrinology 2009;150:2723-2731.

[87] Chu CH, Tzang BS, Chen LM, Kuo CH, Cheng YC, Chen LY, Tsai FJ, Tsai CH, Kuo WW, Huang CY: IGF-II/mannose-6-phosphate receptor signaling induced cell hypertrophy and atrial natriuretic peptide/BNP expression via Galphaq interaction and protein kinase C-alpha/CaMKII activation in H9c2 cardiomyoblast cells. J Endocrinol 2008;197:381-390.

[88] Chang MH, Kuo WW, Chen RJ, Lu MC, Tsai FJ, Kuo WH, Chen LY, Wu WJ, Huang CY, Chu CH: IGF-II/mannose 6-phosphate receptor activation induces metalloproteinase-9 matrix activity and increases plasminogen activator expression in H9c2 cardiomyoblast cells. J Mol Endocrinol 2008;41:65-74.

[89] Su EJ, Cioffi CL, Stefansson S, Mittereder N, Garay M, Hreniuk D, Liau G: Gene therapy vector-mediated expression of insulin-like growth factors protects cardiomyocytes from apoptosis and enhances neovascularization. Am J Physiol Heart Circ Physiol 2003;284:H1429-H1440.

[90] Chen Z, Ge Y, Kang JX: Down-regulation of the M6P/IGF-II receptor increases cell proliferation and reduces apoptosis in neonatal rat cardiac myocytes. BMC Cell Biol 2004;5:15.

[91] Toretsky JA, Helman LJ: Involvement of IGF-II in human cancer. J Endocrinol 1996;149:367-372.

[92] Mann JR, Szabo PE, Reed MR, Singer-Sam J: Methylated DNA sequences in genomic imprinting. Crit Rev Eukaryot Gene Expr 2000;10:241-257.

[93] Sakatani T, Kaneda A, Iacobuzio-Donahue CA, Carter MG, de Boom WS, Okano H, Ko MS, Ohlsson R, Longo DL, Feinberg AP: Loss of imprinting of Igf 2 alters intestinal maturation and tumorigenesis in mice. Science 2005;307:1976-1978.

[94] Kaneda A, Feinberg AP: Loss of imprinting of IGF2: a common epigenetic modifier of intestinal tumor risk. Cancer Res 2005;65:11236-11240.

[95] Kaneda A, Wang CJ, Cheong R, Timp W, Onyango P, Wen B, IacobuzioDonahue CA, Ohlsson R, Andraos R, Pearson MA, Sharov AA, Longo DL, Ko MS, Levchenko A, Feinberg AP: Enhanced sensitivity to IGF-II signaling links loss of imprinting of IGF2 to increased cell proliferation and tumor risk. Proc Natl Acad Sci U S A 2007;104:20926-20931.

[96] Pravtcheva DD, Wise TL: Metastasizing mammary carcinomas in H19 enhancers-Igf2 transgenic mice. J Exp Zool 1998;281:43-57.

[97] Wise TL, Pravtcheva DD: Delayed onset of Igf2-induced mammary tumors in Igf2r transgenic mice. Cancer Res 2006;66:1327-1336. 
[98] McCann AH, Miller N, O'Meara A, Pedersen I, Keogh K, Gorey T, Dervan PA: Biallelic expression of the IGF2 gene in human breast disease. Hum Mol Genet 1996;5:1123-1127.

[99] Singh SK, Moretta D, Almaguel F, De LM, De Leon DD: Precursor IGF-II (proIGF-II) and mature IGF-II (mIGF-II) induce Bcl-2 And Bcl-X L expression through different signaling pathways in breast cancer cells. Growth Factors 2008;26:92-103.

[100] Richardson AE, Hamilton N, Davis W, Brito C, De LD: Insulin-like growth factor-2 (IGF-2) activates estrogen receptor-alpha and -beta via the IGF-1 and the insulin receptors in breast cancer cells. Growth Factors 2011;29:82-93.

[101] Christofori G, Naik P, Hanahan D: A second signal supplied by insulin-like growth factor II in oncogene-induced tumorigenesis. Nature 1994;369:414-418.

[102] Christofori G, Naik P, Hanahan D: Deregulation of both imprinted and expressed alleles of the insulin-like growth factor 2 gene during beta-cell tumorigenesis. Nat Genet 1995;10:196-201.

[103] Douglas JB, Silverman DT, Pollak MN, Tao Y, Soliman AS, StolzenbergSolomon RZ: Serum IGF-I, IGF-II, IGFBP-3, and IGF-I/IGFBP-3 molar ratio and risk of pancreatic cancer in the prostate, lung, colorectal, and ovarian cancer screening trial. Cancer Epidemiol Biomarkers Prev 2010;19:2298-2306.

[104] Micha AE, Hahnel S, Friess H, Buchler MW, Adler G, Gress TM: Genomic imprinting of IGF-II and $\mathrm{H} 19$ in adult human pancreatic tissues. Digestion 1999;60:477-483.

[105] Dejeux E, Olaso R, Dousset B, Audebourg A, Gut IG, Terris B, Tost J: Hypermethylation of the IGF2 differentially methylated region 2 is a specific event in insulinomas leading to loss-of-imprinting and overexpression. Endocr Relat Cancer 2009;16:939-952.

[106] Zhu CQ, Popova SN, Brown ER, Barsyte-Lovejoy D, Navab R, Shih W, Li M, Lu M, Jurisica I, Penn LZ, Gullberg D, Tsao MS: Integrin alpha 11 regulates IGF2 expression in fibroblasts to enhance tumorigenicity of human non-smallcell lung cancer cells. Proc Natl Acad Sci U S A 2007;104:11754-11759.

[107] Soroceanu L, Kharbanda S, Chen R, Soriano RH, Aldape K, Misra A, Zha J, Forrest WF, Nigro JM, Modrusan Z, Feuerstein BG, Phillips HS: Identification of IGF2 signaling through phosphoinositide-3-kinase regulatory subunit 3 as a growth-promoting axis in glioblastoma. Proc Natl Acad Sci U S A 2007;104:3466-3471.

[108] Ravenel JD, Broman KW, Perlman EJ, Niemitz EL, Jayawardena TM, Bell DW, Haber DA, Uejima H, Feinberg AP: Loss of imprinting of insulin-like growth factor-II (IGF2) gene in distinguishing specific biologic subtypes of Wilms tumor. J Natl Cancer Inst 2001;93:1698-1703. 
[109] van Gurp RJ, Oosterhuis JW, Kalscheuer V, Mariman EC, Looijenga LH: Biallelic expression of the H19 and IGF2 genes in human testicular germ cell tumors. J Natl Cancer Inst 1994;86:1070-1075.

[110] Hashimoto K, Azuma C, Koyama M, Ohashi K, Kamiura S, Nobunaga T, Kimura T, Tokugawa Y, Kanai T, Saji F: Loss of imprinting in choriocarcinoma. Nat Genet 1995;9:109-110.

[111] Suzuki H, Ueda R, Takahashi T, Takahashi T: Altered imprinting in lung cancer. Nat Genet 1994;6:332-333.

[112] Douc-Rasy S, Barrois M, Fogel S, Ahomadegbe JC, Stehelin D, Coll J, Riou G: High incidence of loss of heterozygosity and abnormal imprinting of $\mathrm{H19}$ and IGF2 genes in invasive cervical carcinomas. Uncoupling of H19 and IGF2 expression and biallelic hypomethylation of H19. Oncogene 1996;12:423-430.

[113] Vu TH, Yballe C, Boonyanit S, Hoffman AR: Insulin-like growth factor II in uterine smooth-muscle tumors: maintenance of genomic imprinting in leiomyomata and loss of imprinting in leiomyosarcomata. J Clin Endocrinol Metab 1995;80:1670-1676.

[114] Roy RN, Gerulath AH, Cecutti A, Bhavnani BR: Loss of IGF-II imprinting in endometrial tumors: overexpression in carcinosarcoma. Cancer Lett 2000;153:67-73.

[115] O'Gorman DB, Costello M, Weiss J, Firth SM, Scott CD: Decreased insulin-like growth factor-II/mannose 6-phosphate receptor expression enhances tumorigenicity in JEG-3 cells. Cancer Res 1999;59:5692-5694.

[116] O'Gorman DB, Weiss J, Hettiaratchi A, Firth SM, Scott CD: Insulin-like growth factor-II/mannose 6-phosphate receptor overexpression reduces growth of choriocarcinoma cells in vitro and in vivo. Endocrinology 2002;143:42874294.

[117] Ogawa O, McNoe LA, Eccles MR, Morison IM, Reeve AE: Human insulin-like growth factor type I and type II receptors are not imprinted. Hum Mol Genet 1993;2:2163-2165.

[118] Kalscheuer VM, Mariman EC, Schepens MT, Rehder H, Ropers HH: The insulin-like growth factor type-2 receptor gene is imprinted in the mouse but not in humans. Nat Genet 1993;5:74-78.

[119] Xu Y, Goodyer CG, Deal C, Polychronakos C: Functional polymorphism in the parental imprinting of the human IGF2R gene. Biochem Biophys Res Commun 1993;197:747-754.

[120] Martin-Kleiner I, Gall TK: Mannose-6-phosphate/insulin-like growth factor 2 receptor (M6P/IGF2R) in carcinogenesis. Cancer Lett 2010;289:11-22.

[121] Xu YQ, Grundy P, Polychronakos C: Aberrant imprinting of the insulin-like growth factor II receptor gene in Wilms' tumor. Oncogene 1997;14:1041-1046. 
[122] Kuhlmann JD, Schwarzenbach H, Otterbach F, Heubner M, Wimberger P, Worm KH, Kimmig R, Kasimir-Bauer S: Loss of heterozygosity proximal to the M6P/IGF2R locus is predictive for the presence of disseminated tumor cells in the bone marrow of ovarian cancer patients before and after chemotherapy. Genes Chromosomes Cancer 2011;50:598-605.

[123] Frasca F, Pandini G, Scalia P, Sciacca L, Mineo R, Costantino A, Goldfine ID, Belfiore A, Vigneri R: Insulin receptor isoform A, a newly recognized, highaffinity insulin-like growth factor II receptor in fetal and cancer cells. Mol Cell Biol 1999;19:3278-3288.

[124] Pandini G, Conte E, Medico E, Sciacca L, Vigneri R, Belfiore A: IGF-II binding to insulin receptor isoform $A$ induces a partially different gene expression profile from insulin binding. Ann N Y Acad Sci 2004;1028:450-456.

[125] Vella V, Pandini G, Sciacca L, Mineo R, Vigneri R, Pezzino V, Belfiore A: A novel autocrine loop involving IGF-II and the insulin receptor isoform-A stimulates growth of thyroid cancer. J Clin Endocrinol Metab 2002;87:245-254.

[126] Sciacca L, Costantino A, Pandini G, Mineo R, Frasca F, Scalia P, Sbraccia P, Goldfine ID, Vigneri R, Belfiore A: Insulin receptor activation by IGF-II in breast cancers: evidence for a new autocrine/paracrine mechanism. Oncogene 1999;18:2471-2479.

[127] Sciacca L, Mineo R, Pandini G, Murabito A, Vigneri R, Belfiore A: In IGF-I receptor-deficient leiomyosarcoma cells autocrine IGF-II induces cell invasion and protection from apoptosis via the insulin receptor isoform A. Oncogene 2002;21:8240-8250.

[128] Brierley GV, Macaulay SL, Forbes BE, Wallace JC, Cosgrove LJ, Macaulay VM: Silencing of the insulin receptor isoform A favors formation of type 1 insulin-like growth factor receptor (IGF-IR) homodimers and enhances ligandinduced IGF-IR activation and viability of human colon carcinoma cells. Endocrinology 2010;151:1418-1427. 


\section{Figure legends}

Figure 1. Affinity of IGF-II for its various receptors. IGF1R - type 1 IGF receptor; IGF2R - type 2 / mannose-6-phosphate receptor; IR - insulin receptor. The IGF1R can form hybrids with either IR-A or IR-B.

Figure 2. Signalling pathways activated following IGF-II binding to the type 1 or type 2 IGF receptor (IGF1R and IGF2R; Panel $A$ and $B$ respectively). PKC - protein kinase C; PLC - phospholipase C; CaMKII - Calcium/calmodulin dependent protein kinase II; MMP matrix metalloproteinase. Leu ${ }^{27}$ IGF-II - IGF-II analogue that binds primarily to IGF2R; pathways identified through the use of this analogue are shown in red. 
Figure 1

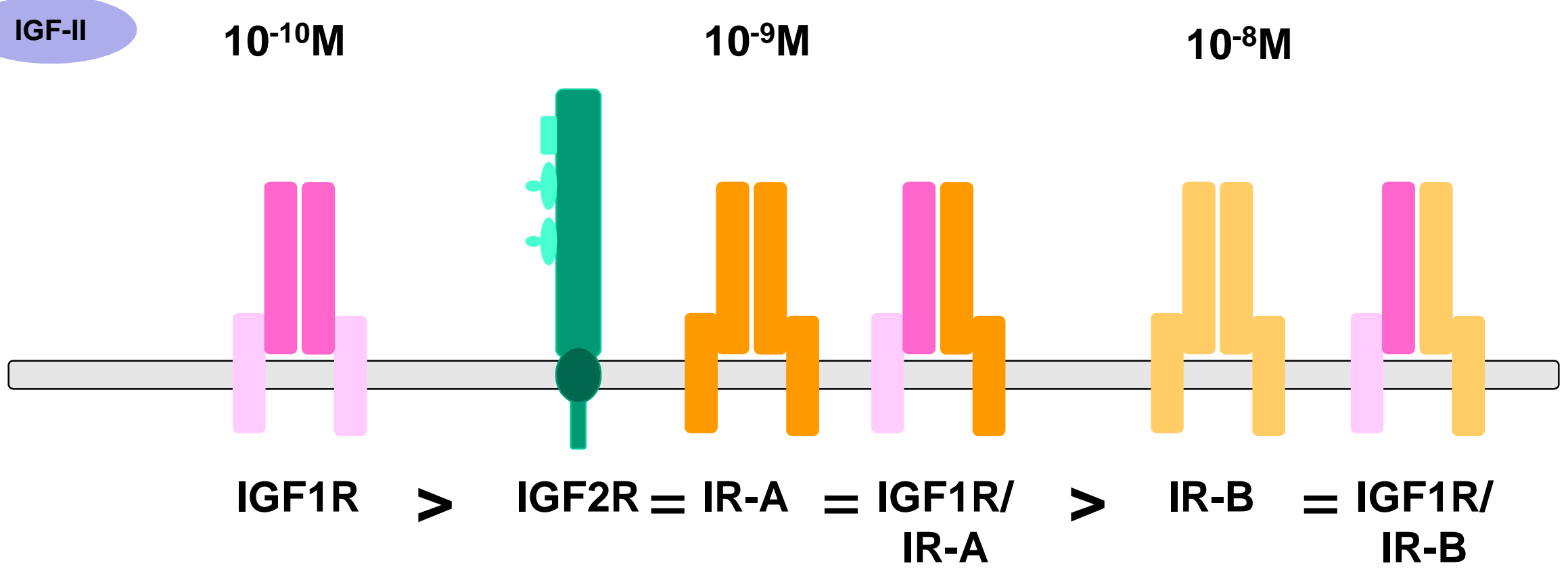


Figure 2A

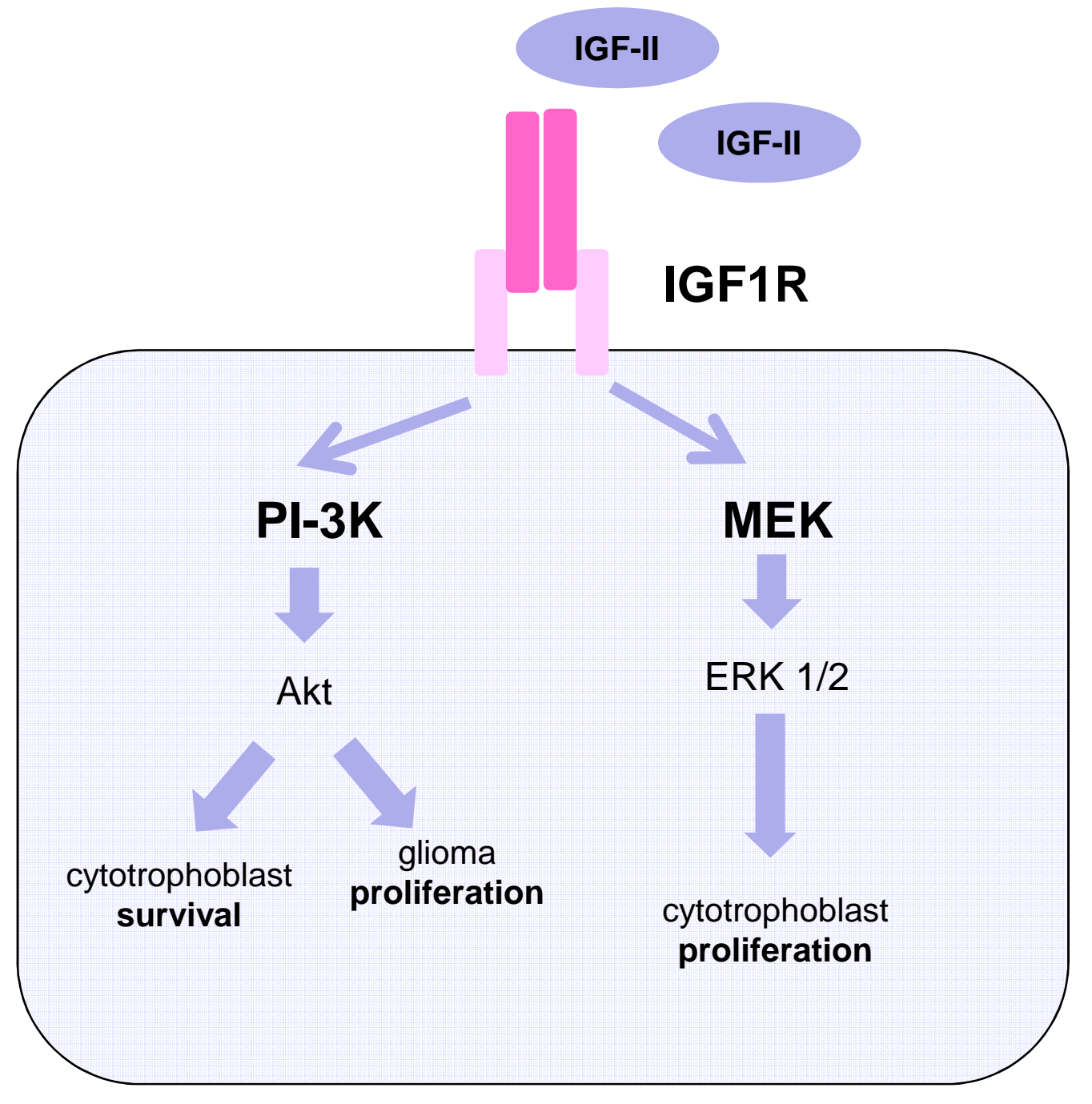




\section{Figure 2B}

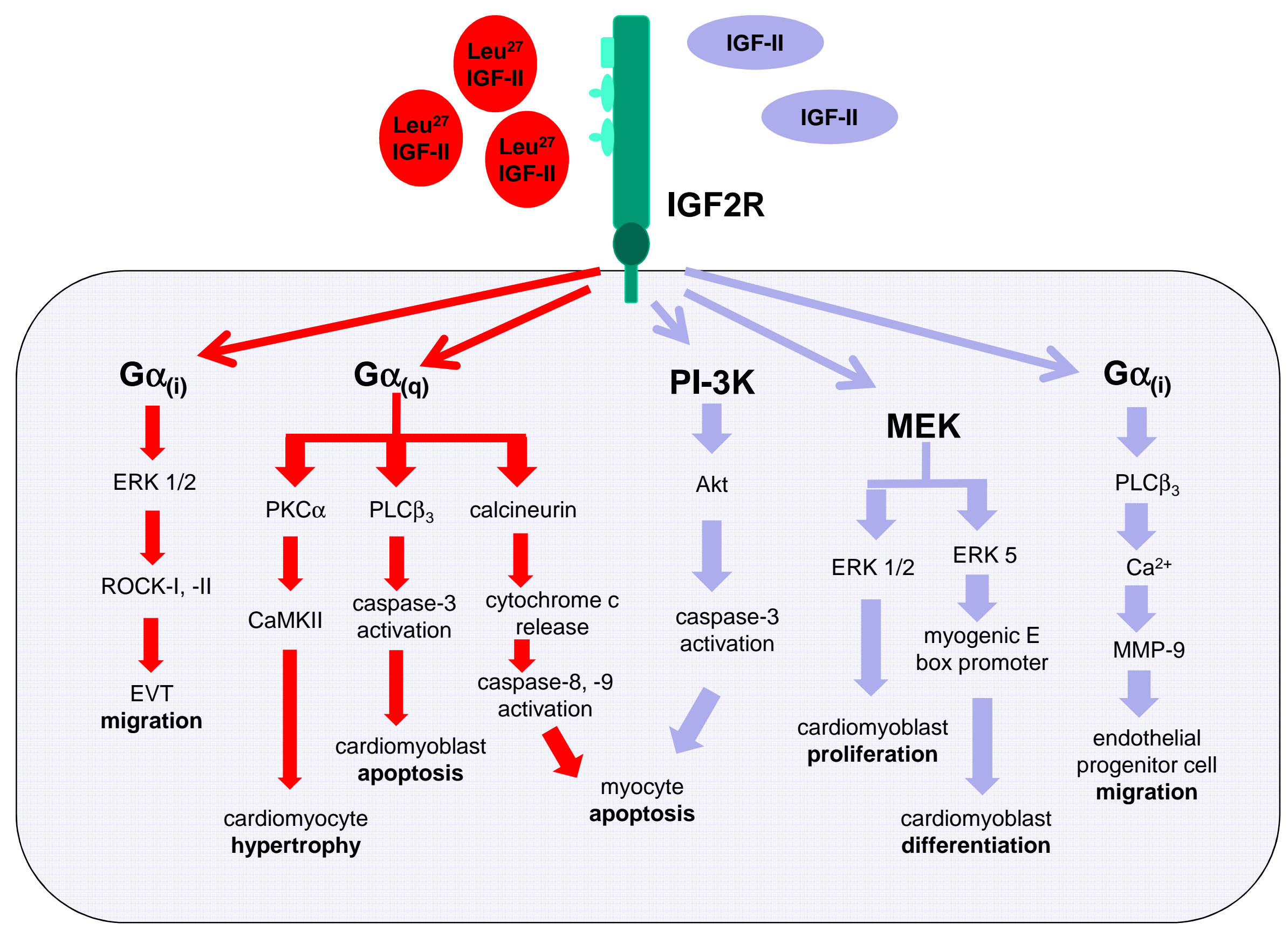

